\title{
Disentangling THE WEALTH EFFECT: A Cohort Analysis OF Household SAVING IN THE 1990S
}

\author{
Dean M. Maki and Michael G. Palumbo*
}

\begin{abstract}
In the U.S., household net worth rose substantially in the latter half of the 1990s and the personal saving rate decreased rapidly. Researchers have not reached a consensus about just how these two events are linked, or how to interpret the negative correlation between wealth and the saving rate over a longer time span. The movements in net worth and the saving rate are consistent with a direct view of the wealth effect, in which an increase in wealth directly causes households to increase their consumption and decrease their saving. However, the aggregate data do not rule out alternative explanations for the time series correlation: either indirect wealth effects or reverse causation running from changes in household saving to changes in wealth. In this paper, we analyze a unique database constructed using household-level data from the Survey of Consumer Finances and aggregate data from the Flow of Funds Accounts. These data allow us to estimate net worth and saving for different demographic groups over the period surrounding the stock market boom in the 1990s. We find that the groups of households that benefited the most from the recent runup in equity wealth--those with high incomes or who have attained some college education--were also the groups that substantially decreased their rates of saving. Further, econometric analysis of these data produces coefficient estimates for the propensity to consume out of wealth that are closely aligned with typical estimates obtained from aggregate data. Taken together, our results corroborate a direct view of the wealth effect on consumption.
\end{abstract}

April 2001

\footnotetext{
Maki: Putnam Investments, One Post Office Square, Boston, Massachusetts 02109, dean_maki@putnaminv.com; Palumbo: Division of Research and Statistics, Mail Stop 80, Board of Governors of the Federal Reserve System, Washington, DC 20551, mpalumbo@ frb.gov. Most of the work on this paper was completed when Maki was at the Federal Reserve Board. This project originated from an idea of Alan Greenspan's to merge information from the Survey of Consumer Finances with the Flow of Funds. We would also like to thank Arthur Kennickell for providing the balance sheet data from the 1989 through 1998 Surveys of Consumer Finances broken down by income quintile and education category. We have benefited from discussions with many of our colleagues at the Federal Reserve Board. In particular, we received detailed comments on an earlier draft from Stephanie Aaronson, Darrel Cohen, Julia Coronado, Karen Dynan, Doug Elmendorf, Maria Perozek, and Larry Slifman, as well as excellent research assistance from David Brown, Shital Patel, and Jennifer Scherschel. The views expressed belong to the authors and should not be attributed to the Board of Governors of the Federal Reserve System, the Board's staff, or Putnam Investments.
} 


\section{INTRODUCTION}

The net worth of American households increased sharply over the second half of the 1990s, owing primarily to the extraordinary performance of corporate equity prices in U.S. markets sustained through 1999. A potential implication of this new-found wealth is that it could directly explain the pickup in the pace of consumer spending in the U.S. over the past few years. By now, the coincident acceleration in the rate of decline in the personal saving rate and the steep rise in the ratio of household net worth to disposable income --reproduced in figure 1--qualifies as common knowledge. Previous macroeconomic research indicates that the aggregate data on consumption, income, and wealth are consistent with a significant and direct effect of wealth on consumption, whereby consumer spending eventually rises on the order of 3 to 5 cents for every extra dollar of wealth that is recognized by households and sustained over a period of time. Indeed, a direct wealth effect of this magnitude is capable of providing a fairly accurate description of aggregate consumption, income, and wealth over both the recent episode (since 1995) and the longer post-war period. ${ }^{1}$

That said, the reasonable degree of consensus regarding the nature of the long-run statistical relationships between consumption, income, and wealth in the aggregate U.S. data has not resulted in a consensus regarding just what economic behavior underlies the aggregate empirical trends. In particular, some researchers have specifically warned against interpreting these statistical relationships as indicating a direct role for changes in wealth to determine future consumption growth rates. For example, Poterba and Samwick (1995) highlight the case for an indirect channel relating stock-market movements to consumption changes. According to their view, occasional changes in some unidentified economic factors may produce movements in both the stock market and consumption, so that while the stock market tends to act as a "leading indicator" of consumer spending, changes in the former may not, per se, cause changes in the

\footnotetext{
${ }^{1}$ Poterba (2000) provides a useful broad introduction to this topic, and Davis and Palumbo (2001) fill in some details regarding specific econometric and data issues surrounding the estimation of wealth effects with time-series data. Muellbauer and Lattimore (1995; also see Muellbauer, 1994) thoroughly survey a wide range of theoretical and empirical macroeconomic research on the consumption function. In addition to presenting new estimates on the wealth effect using household-level data, Dynan and Maki (2000; discussed later in the paper) review the extant microeconomic research.
} 
latter. Going somewhat further, Ludvigson and Steindel (1999) report time-series regressions in which movements in the stock market have essentially no predictive power for subsequent consumption growth in the short run, indicating the absence of either a direct or indirect wealth effect on spending. Kiley (2000) demonstrates that, at least in theory, an economic story involving a "consumption effect on wealth"--a channel of "reverse" causality in which changes in consumption lead to changes in the stock market--is about as capable of generating the stylized patterns evident in the aggregate data as the more usual and intuitive story about a "wealth effect on consumption." Finally, note that without clear evidence on spending patterns across the wealth distribution over time, some analysts have wondered whether the magnitude of the increases associated with the consumption boom in the latter 1990s can even plausibly be accounted for by changes in the consumption expenditures of the wealthiest Americans, as a direct wealth effect would imply--an issue our analysis directly addresses.

This paper contributes to the discussion by investigating the evidence for a direct wealth effect on consumption by analyzing a new source of data that combines macroeconomic and microeconomic data. Our investigation into the direct role of wealth effects over the 1990s relies equally on aggregate data--economy-wide saving of the household sector as measured by the Flow of Funds accounts--and household-level data--balance sheet information for a representative sample of families from the triennial Survey of Consumer Finances. Using these primary sources, we have constructed quarterly time series for saving rates and net worth-income ratios for a few selected cohorts of families--rather than for the aggregate of all families or for a cross-section of many families--covering the $1990 \mathrm{~s}^{2}$ Thus, our database preserves the time-series variation in net worth-income ratios critical for identifying potential wealth effects--variation that the previous macroeconomic research has relied upon--but also allows us to directly examine whether those families who most benefited from the stock market performance are those whose saving rates declined the most, a question that cannot be addressed with aggregate data.

\footnotetext{
${ }^{2}$ Throughout the paper, we use the term cohort to refer to households with similar positions in the crosssection distributions of income or education, not in reference to individuals born in the same year (which is how demographers typically use the term).
} 
Our main result is descriptive in nature. We show that the groups of families whose portfolios were boosted the most by the exceptional stock market performance over the latter half of the 1990s are the same groups whose net saving flows fell the sharpest from 1995 through 2000. Indeed, families who owned relatively modest shares of corporate equity--the vast majority of American households--experienced relatively mild gains in net worth-income ratios over the 1990s and continued to invest in new saving at about the same steady pace throughout the decade. This descriptive result reveals a direct link between the extraordinary performance of the stock market and increased spending rates by the households whose portfolios appreciated the most. In addition, our study verifies that essentially all of the increased spending apparent in the aggregate data (the acceleration in the saving rate's decline shown in figure 1) can be attributed to an increase in the propensity to consume out of income undertaken by the richest households in the U.S. Finally, we present new econometric estimates of the propensity to consume out of household net worth based on our cohort-level, time-series data that fall into the same range--3 to 5 cents to the dollar--as the typical macroeconomic estimates. These econometric results bolster our conclusion that a direct view of the wealth effect on household spending is of the right size to explain the sharp decline in the aggregate saving rate observed over the 1990s.

The paper is organized as follows. The first section describes in some detail our procedures for constructing the cohort-level, time-series data from the aggregate-level Flow of Funds and the household-level Surveys of Consumer Finances. Next, we demonstrate that the trends in net worth and saving by income quintile and education category are consistent with a direct view of the wealth effect. In the third section, we apply simple regression analysis to the cohort-level data to produce new estimates of the marginal propensity to consume out of wealth. The last section of the paper presents the conclusions of our study. 


\section{A New Source of Data}

\section{Background}

The dataset that we analyze in this paper comes from combining information from two primary sources. First, detailed data on the level of net worth, the composition of the balance sheet, and the net flows of dollars into various asset and liability categories for the aggregate household sector are published quarterly in the Flow of Funds Accounts (FFA). Second, data describing how the composition of balance sheets--that is, detailed holdings for a wide range of asset and liability types--is distributed in the cross-section among a representative sample of households are provided every three years by the Survey of Consumer Finances (SCF). ${ }^{3}$ The SCF also includes information on disposable income and education that we use to construct cohorts of households. Our procedures allocate the quarterly FFA data on aggregate net worth levels and saving flows to different cohorts of households based on the distribution of balance-sheet compositions in the nearest SCF. These produce two panel datasets consisting of quarterly observations on saving flows and net worth levels (both measured in relation to disposable personal income)--one for "income cohorts," another for "education cohorts". 4

Our methods for using the household-level data in the SCF waves to allocate the aggregate data in the FFA provide statistical power--beyond that available from the aggregate FFA data alone--to the extent that holdings of assets and liabilities are distributed unevenly across the cohorts of households. We initially used quintiles of the disposable income distribution in the SCF waves to define income cohorts. It was immediately clear that this income-split delivered the needed variation in household balance sheets across groups to serve our statistical purposes. However, splitting the sample by income quintile means that households can, in principle, switch

\footnotetext{
${ }^{3}$ Both primary data sources are available from the Federal Reserve Board. Flow of Funds data can be obtained at: http://www.federalreserve.gov/releases/Z1/ . Saving flows can be found in tables F.9 and F.100; net worth levels are in table B.100. Information about the Surveys of Consumer Finances is available at: http://www.federalreserve.gov/pubs/oss/oss2/scfindex.html .

${ }^{4}$ As we describe in further detail below, we actually present results from four separate datasets: for each of the income and education groupings, we consider two alternative definitions of the "household sector."
} 
between groups over time, which could affect our estimates. Thus, to test the robustness of our results, we also constructed a dataset for education cohorts, using the following levels of attained education to split households: less than high school, high school graduate, some college, and college graduate. ${ }^{5}$ Splitting by education levels has the advantage of ensuring that very few households switch between groups over time, but also has the disadvantage of contrasting the behavior of relatively older American households (who are disproportionately distributed in the lower two education categories) with that of relatively younger ones. Thus, in this paper we present a full set of results for both the income- and education-cohort datasets, and the consistency of our results between the two methods reassures us that our results are robust.

To better understand the specifics of our data-construction procedures, it is useful to examine a sample of the underlying SCF data that we use. Table 1 reports the shares of aggregate assets and liabilities held by households in the uppermost twenty percent of the household income distribution as estimated using the triennial SCF waves from 1989 through $1998 .{ }^{6}$ We have combined the raw SCF survey data into these particular asset and liability categories to facilitate matching them with the published FFA data, as recommended by Antoniewicz (1996). Relative to their share of the population, households in the top income quintile owned a disproportionate share of all of the listed asset and liability categories, though the magnitude of these shares vary considerably across types of assets. ${ }^{7}$ In 1989, for example, these ownership shares ranged from a low of 40 percent for the stock of consumer durable goods (line 2) and "other" insurance policy payables (line 18) to highs of 99.5 percent for security credit and 92.3 percent of investment in bank personal trusts (lines 21 and 16). One key point is that in the categories of directly-held

\footnotetext{
${ }^{5}$ In the case of married couples in the SCF, we assign the household to an education group based on the level of education attained by the member of the couple with the most schooling.

${ }^{6}$ Tables similar to table 1 for the other four quintiles of the income distribution and for all four education categories that we examine are available on request. Note that we are using the SCF's population weights to aggregate the household-level data to the cohort level.

${ }^{7}$ As appendices A and B report, the upper income quintile accounted for about 44 percent of aggregate disposable income and roughly 60 percent of aggregate net worth in the 1990s.
} 
corporate equity, both publicly traded and closely held (lines 11 and 12), the top income quintile held more than 80 percent of the total stock in every SCF wave. Also, although holdings of mutual funds and defined-benefit pension plans became somewhat more evenly distributed over the 1990s, even in 1998 the top income quintile held about three-quarters and two-thirds of these assets, respectively.

Thus, perhaps unsurprisingly, the data show that the exceptional performance of the U.S. stock market over the 1994-1999 period served to boost overall net worth ratios disproportionately at the upper end of the income distribution through appreciation in corporate equity held directly, and indirectly in mutual funds, bank personal trusts, and defined-contribution pension plans.

Regarding the liability categories in table 1 , the highest-income quintile held the vast majority of security credit (which includes margin debt), but home mortgages and consumer credit were more widely held than most of the asset categories. Another noteworthy feature of the data reported in table 1 (and in the other tables not explicitly reported here) is that--apart from assets that are held by a very small portion of the population, such as municipal bonds, mortgage assets, and investment in bank personal trusts--the balance sheet shares of the top income group (and the other four quintiles) do not typically fluctuate very much from wave to wave in the SCF.

The other primary source used to construct our dataset is the Flow of Funds Accounts. These aggregate data are published quarterly by the Federal Reserve Board, and represent the financial counterpart to the National Income and Product Accounts (NIPA) published by the Bureau of Economic Analysis (BEA). The FFA includes information on the aggregate household sector's net worth, the composition of its balance sheet, and the net flows into many detailed asset and liability categories. As in the NIPA, the household sector includes both the holdings of households and those of nonprofit organizations.

Adding together the net financial flows across the various asset and liability categories, the FFA provides an independent measure of household saving that can be compared with the personal saving rate published in the NIPA. Household saving as measured by NIPA is the 
difference between disposable personal income and personal outlays, whereas saving in the FFA is measured by the net acquisition of financial assets plus net investment in tangible assets less the net increase in liabilities. ${ }^{8}$

Figure 2 shows that movements in the FFA and NIPA saving rate series have diverged at some points historically--most recently from 1989 through 1991--but typically have tracked each other reasonably well. ${ }^{9}$ However, the FFA saving series is noticeably more volatile than the NIPA series. (Note that both measures are seasonally adjusted and both have been smoothed in figure 2 by taking four-quarter moving averages.) Because the NIPA saving rate is more commonly referenced, some may be tempted to dismiss the flow of funds data as "too" volatile, but it is not clear which of the two series accords better with the "true" rate of household saving in the economy. Although many of the primary data happen to move around quite a bit from quarter to quarter, the quarterly FFA estimates are based largely on reports received directly from financial institutions--ostensibly, a group of proficient book-keepers.

Our analysis focuses on the FFA measure of aggregate household saving, and our primary analysis includes quarterly data from 1992 through 2000, when the NIPA and FFA saving rates declined by similar amounts. Importantly, we study the effects on household saving over a time period in which stock prices nearly tripled. ${ }^{10}$

\footnotetext{
${ }^{8}$ In the NIPA, personal outlays are the sum of personal consumption expenditures, interest payments to businesses, and net transfers to the rest of the world.

${ }^{9}$ Actually, the FFA publishes two different measures of household saving based on different conceptual definitions of saving. Figure 2 plots the FFA measure of the aggregate personal saving rate that is the focus of this study. This saving concept is designed to be conceptually equivalent to the NIPA personal saving rate (as it is currently published), and is measured using FFA data on financial flows for the household and nonprofit sector. The FFA also contains a second saving concept that includes net investment in consumer durable goods as saving. In this study, we also examine an alternative measure of personal saving which omits saving associated with nonprofit organizations and flows into defined-benefit pension plans (as well as expenditures on consumer durable goods). Note that all of these saving rates-NIPA and FFA--exclude capital gains from saving.

${ }^{10}$ Note that, because we are relying on the SCF data for our decomposition across income and education groups, we are limited in how far back we could extend the analysis. The SCF staff advised us not to use the 1983 survey in this analysis because of methodological differences between that and later surveys. Because of the divergence in trend between the NIPA and FFA saving rates in the 1989-91 period, we chose to start
} 


\section{Procedures}

We use a multi-step process to combine information from the triennial SCF waves and the quarterly FFA. Our procedures rely on the distribution of balance sheet shares across income and education cohorts--such as the example for the upper income quintile shown in table 1--estimated from the SCFs to allocate the FFA holdings in each liability and asset category to the respective groups of households. First, with the help of SCF staff, we mapped the SCF data, which include balance-sheet information for a highly disaggregated set of assets and liabilities, into categories compatible with the FFA data. Second, using each SCF, we computed the shares of each asset and liability category that belonged to households in the respective income or education cohorts. Third, we allocated each FFA asset and liability category in proportion to the balance sheet shares associated with the respective income and education cohorts.

How do we handle quarters falling in between the triennial SCF waves? We (linearly) interpolate the asset and liability shares for each income and education cohort between the two nearest SCF waves, and we use shares from the 1998 SCF for all subsequent quarters. Because the shares are stable across the SCF waves, neither our descriptive nor econometric results are sensitive to applying different interpolation methods to the triennial SCF waves in allocating the quarterly FFA data.

These allocation procedures result in a set of databases of net worth by income and education cohorts. Adding across the five income or four education groups, the level of each asset and liability category in our databases matches the published value for the household sector in the FFA (and, thus, net worth in our data adds up to total FFA net worth). Also, for each asset and liability category, the distribution of balance-sheet shares across income and education groups is consistent with the distribution in each of the SCF waves.

our baseline analysis in 1992, but our results are not very sensitive to having ignored the earlier data. Regression estimates of the size of the "wealth effect" (presented below) were a bit smaller using the incomecohort data back through 1989 (ranging closer to 3-1/2 cents to the dollar), but these were always statistically significant. Regression estimates based on the education-cohort data back through 1989 were very close to those reported in the text. 
So far, our description has focused on how we have constructed panel datasets for quarterly net worth levels by income quintile and education category. How do we allocate FFA saving flows? We use the same procedures that we used to allocate the levels. That is, we allocate the FFA saving flows to the respective income and education cohorts, asset-by-asset and liability-by-liability, in direct proportion to the balance-sheet shares constructed from the SCF waves (linearly interpolating between the triennial waves to get quarterly shares).

The stability in the balance-sheet shares across the SCF waves that we mentioned previously (in the context of table 1) motivates this choice. Had the distribution of the flows been very different, then the balance-sheet shares would have moved more noticeably between the 1989 and 1998 SCF waves. Put another way, we assume that while rates of return naturally varied across asset and liability categories, within the same asset and liability category returns did not vary systematically across income or education groups. ${ }^{11}$ Thus, according to our thinking, the documented stability in the balance-sheet shares indicates that in the 1990s flows were made in about the same proportion to levels, within a given asset or liability category. Furthermore, by benchmarking the shares to the triennial SCF data and interpolating between the SCF waves, our procedures yield flows that are consistent with the modest shifts in balance sheets that did occur over this period. ${ }^{12}$

We measure saving flows and net worth levels as a proportion of disposable income, and this approach requires allocating the aggregate, quarterly NIPA data on disposable personal income to the income and education groups. To accomplish this, we use estimated distributions of disposable income among the income quintiles and education categories published (annually) by the Census Bureau, which are based on underlying data from the March Current Population

\footnotetext{
${ }^{11}$ Of course, the composition of the balance sheet differs substantially by income and education so that there will be substantial variation in rates of return for the total portfolio across groups.

${ }^{12}$ To reinforce these points, we experimented with applying our allocation procedures using a fixed set of balance-sheet shares taken from one of the SCF waves (for example, from the 1995 SCF) and applying these shares throughout the sample period. Results from these experiments--using any of the four SCF waves-were very similar to those discussed in the paper, leading us to believe that our particular choice of interpolation is not driving the results.
} 
Surveys (CPS). ${ }^{13}$

An example of our saving allocation may help to clarify our procedures. The aggregate FFA data indicate that households have been net sellers of directly-held corporate equities in recent years. Because shares of directly-held corporate equities owned by the various income and education groups did not change much between the SCF waves, it is reasonable to assume that households sold equities in proportion to their prior holdings. Intuitively, because the households in the uppermost income quintile held more than 80 percent of aggregate directly-held corporate equities in each of the SCF waves, these high-income households must have been undertaking the vast majority of the selling over this period. Therefore, all else being equal, our procedures interpret a drop-off in net flows of directly-held corporate equity as an indicator of reduced saving by high-income households. This would show up as reduced saving for the high-income group, unless the FFA data were to record offsetting run-ups in net flows for other categories of assets also owned disproportionately by the richest families.

Below, we present data showing sharp downward trends in saving rates by the highestincome households and relatively flat saving rates over the 1992-2000 period for households with moderate income levels. This pattern obtains because over the decade, on balance, it was dropoffs in the net flows into financial asset and pick-ups in the rate of liability accumulation for financial instruments typically held by upper income American households that accounted for virtually all of the decline in the total FFA saving rate. Meanwhile, and in stark contrast, net flows into asset and liability categories owned by the majority of American households--those in the lower 80 percent of the income distribution--held rather steady over the decade.

One technical point is that the recent SCFs do not include estimates of the present value of defined benefit pension assets (DB) at the household level, so it is not obvious how we should

\footnotetext{
${ }^{13}$ Census Bureau estimates of average income by income quintile are published in table $\mathrm{H}-3$ of the "Historical Income Tables: Experimental Income Measures," while estimates of average income by educational attainment appear in tables H-13 and H-14. These tables (and others) are available at: http://www.census.gov/hhes/income/histinc/inchhdet.html. Census estimates were only available through 1998 at the time of our analysis, so we used these to allocate NIPA disposable income in 1999 and 2000. Finally, we use the published annual income shares for each of the four calendar quarters (here, we do not interpolate between years).
} 
allocate this category, which is included in aggregate FFA data on net worth and saving, to the respective income and education groups. The 1983 SCF wave did contain the pertinent information and we perform one analysis using a database that incorporates shares for DB pensions from the 1983 SCF. Because this information may well be out of date in the 1990s, and no comparable data are available from the later surveys, we perform another analysis excluding wealth in DB pension plans from the FFA data. In addition, as mentioned above, both the FFA and NIPA household sectors include the activities of nonprofit organizations. However, to the extent that the saving behavior of families and nonprofits are not identical, we might want to remove nonprofit organizations from our data. The FFA data make it possible to "back out" the saving flows and net worth levels attributed to nonprofits, which we remove (by detailed asset and liability category) before undertaking our allocation procedure. ${ }^{14}$

Thus, we present two symmetric pairs of analyses throughout the paper: The first measures saving and net worth for the household sector inclusive of DB pension plans and nonprofit organizations, as in the benchmark published FFA data; the second refers to a "pure" household sector, in which we have omitted the saving and net worth that can be attributed to DB pension plans and nonprofits. In the end, our results from these two alternative methods turn out to be quite similar. ${ }^{15}$

To summarize, in every quarter our dataset matches the levels of net worth and saving for the household sector published in the Flow of Funds when aggregated across our income or

\footnotetext{
${ }^{14}$ FFA estimates of nonprofit assets and liabilities are based on data from the IRS Statistics of Income, and are available only with a three-year lag. We assume no change in nonprofit shares for each asset and liability category through 2000, except for corporate equities. In this category, the nonprofit flows are quite volatile, and have been both positive and negative in recent years. Because it is difficult to predict these data for the 1997-2000 period for nonprofits, we simply assume that nonprofits had zero net purchases of corporate equities in the 1997-2000 period, and allocate the entire net flow to households. The results of our study are robust to varying this assumption.

${ }^{15}$ Note that we have not attempted to estimate or remove NIPA disposable personal income that might be attributed to nonprofit organizations. In this sense, the reported saving rates and net worth-income ratios in our "pure" household sector data (that excludes nonprofits and DB pension plans) are somewhat understated.
} 
education cohorts. ${ }^{16}$ In addition, the distributional data match the SCF in every survey year. Our data offer advantages over other data sets that have been used previously to study wealth effects. In contrast to the aggregate data, we can examine movements in saving and net worth across cohorts (as well as over time), and the cross-cohort evidence is necessary to distinguish between direct and indirect views of the wealth effect. In contrast to most available microeconomic sources, our data appropriately reflect the influence of the wealthiest families--who have typically accounted for a disproportionate share of aggregate income, consumption, saving, and net worth in the U.S. Dynan and Maki (2000) have documented the inability of the aggregated micro-data in the Consumer Expenditure Surveys (CEX) to match the NIPA saving rate from 1994 through 1998--either the level or the trend. ${ }^{17}$ Consistent with the analysis of Sabelhaus (1998), this problem could arise due to the survey's tendency to under-represent families at the top of the income and wealth distributions in its sample coverage, or simply because the top-coding procedures applied to the publicly available data remove valuable information about the behavior of the richest families. By contrast, the wealthiest American households are over-sampled, by design, in the SCF survey and our methods take advantage of this feature to reproduce trends apparent in the aggregate data on saving and net worth.

\section{Descriptive Results}

The logic underlying a direct wealth effect is quite simple: An increase in stock prices increases a household's net worth and, thus, allows an increase in its consumption, holding the level of income constant. Thus, both the level of saving--income less consumption--and the saving rate--saving as a fraction of income--fall. In this section, we simply examine whether the

\footnotetext{
${ }^{16}$ Also, note that, when aggregated across income quintiles or education categories, our income series match the quarterly figures for disposable personal income published by the BEA.

${ }^{17}$ Note, however, that Dynan and Maki (2000) take advantage of the panel-data aspect of the CEX microdata to circumvent this problem. In fact, they find strong evidence for a direct wealth effect by estimating statistically and economically significant correlations between consumption changes and capital gains at the household level over the 1980s and 90s. The concluding section of this paper includes a further comparison of our results with theirs.
} 
groups of families whose portfolios benefited the most from the stock-market boom of the latter 1990s are the same groups whose saving rates dropped the most.

Net worth-income ratios and saving rates by cohort

Tables 2 and 3 report net worth-income ratios and saving rates by income quintile and education category, respectively, for 1992 and 2000. ${ }^{18}$ In the tables, panel A reports statistics based on data for the household sector as defined in the published Flow of Funds accounts, while panel B reports on an alternative definition of the household sector which excludes the activities of defined benefit pension plans and nonprofit organizations from the net worth and saving data. Figures 3 through 6 present all of the quarterly cohort-level observations for net worth-income ratios and saving rates for the cases in which data for DBs and nonprofits have been excluded. ${ }^{19}$ Net worth-income ratios and saving rates are contrasted among the five income quintiles in figures 3 and 4 and are contrasted among households in the four education categories in figures 5 and 6.

Looking first at the income-quintile cohort data, both panels of table 2 show that, between 1992 and 2000, families in the uppermost 20 percent of the income distribution experienced by a wide margin the sharpest increases in net worth-income ratios and decreases in saving rates compared with families in the lower 80 percent of the income distribution. Families at the top of the income distribution began the 1990s with considerably higher saving rates than other families-8-1/2 percent in column (C) of panel A. However, saving rates among the richest households fell so rapidly during the decade--about 10-1/2 percentage points according to the difference between columns (C) and (D) in panel A--that by 2000 they represented the only income group whose

\footnotetext{
${ }^{18}$ For reference, shares of aggregate income, net worth, and consumption (measured, here, as income minus saving) accounted for by our income and education cohorts in 1992 and 2000 are reported in appendix A through $\mathrm{C}$ at the end of the paper.

${ }^{19}$ The data that include activities of DB pension plans and nonprofits in the respective definitions of net worth and saving exhibit extremely similar patterns to those shown in figures 2 through 5 (a sense of this can be gleaned by comparing panels A and B in tables 1 through 4) and, thus, the other graphs have been omitted to conserve space.
} 
spending exceeded their disposable income (a saving rate of -2.1 percent). Families between the $60^{\text {th }}$ and $80^{\text {th }}$ percentiles of the income distribution mildly decreased their rates of saving, as they benefited from moderately higher net worth-income ratios over the 1990s, while both the saving rates and net worth-income ratios were essentially flat, on balance, between 1992 and 2000 among families in the middle income quintile. Meanwhile, among families in the lowest 40 percent of the income distribution, saving rates actually rose noticeably--they nearly doubled between 1992 and 2000--and by 2000 these relatively poor families were saving at considerably higher rates than other American households.

The quarterly cohort data shown in figures 3 and 4 reveal that net worth-income ratios and saving rates were essentially flat between early 1992 and early 1994 for each of the income quintiles. During 1994, net worth-income ratios began stepping up, on balance, for all of the income groups except those in the middle quintile; but figure 3 makes clear that the most dramatic trend break was experienced by households in the uppermost 20 percent of the income distribution. The quarterly saving rates by income quintile are somewhat bumpy, but the upper left panel of figure 4 suggests a substantial break in the trend rate of saving in 1994--from basically flat to briskly declining, on net--among families at the top of the income distribution. Meanwhile, saving rates among households in the third and fourth income quintiles continued to exhibit essentially no trend in the post-1994 period, while saving rates began rising among families in the bottom 40 percent of the income distribution (again, as indicated by the annual data for 1992 and 2000 presented in table 2).

Thus, these cohort-level, time-series data provide new evidence indicating that a pronounced reshuffling in the distribution of saving rates among American households occurred during the 1990s, and that virtually all of the observed decline in the aggregate saving rate can be attributed to a change in the propensity to save out of income among the very households whose portfolios gained the most from the stock market boom over the latter half of the decade. ${ }^{20}$ These

\footnotetext{
${ }^{20}$ We should note that for all of our income and education cohorts capital gains (as opposed to new saving) account for a very large proportion of the overall changes in net worth throughout the 1990s. For example, among households in the uppermost quintile of the income distribution capital gains accounted for about 67
} 
patterns are just as we would expect from a direct view of the wealth effect on consumer spending.

Turning next to the experience among the education cohorts, table 3 and figures 5 and 6 tell a similar story. This cut of the data shows that over the 1990s most of the aggregate increase in the ratio of net worth to income accrued to households headed by a person with some college experience or an advanced education degree, and documents that a corresponding decline in saving rates among these same two cohorts of households accounts for almost all of the overall decline in the aggregate saving rate. Overall, households headed by persons who only attended high school experienced comparatively small changes in their net worth-income ratios and maintained roughly the same saving rates, on balance, between 1992 and 2000. Again, the data reveal a reshuffling in the distribution of household saving rates over the 1990s whereby the cohorts whose portfolios jumped the most in value experienced striking declines in their propensities to consume out of income relative to other households whose portfolios were affected by the stock-market boom to a considerably lesser degree.

\section{Cohort contributions to aggregate net worth-income ratios and saving rates}

The descriptive evidence presented above suggests that the aggregate increase in the household net worth-income ratio and the decrease in the personal saving rate over the 1990s can be attributed almost exclusively to households in the uppermost twenty percent of the income distribution and in the upper two education categories. To more precisely quantify the trends suggested above, tables 4 and 5 decompose the levels of aggregate net worth-income ratios and saving rates in 1992 and 2000--and, thus, the changes in these two series over the intervening eight-year period--into contributions made by households in the various income and education cohorts. $^{21}$ For example, panel B in table 4 shows that between 1992 and 2000 the aggregate net

percent of the increases in net worth during the early 1990s and more than 95 percent after 1994. Among households in the lower portion of the income distribution, capital gains accounted for about 90 percent of the change in net worth in the early 1990s and a little more than 80 percent after 1994.

${ }^{21}$ The contribution to the aggregate ratio--reported by income quintile in table 3 and by education category in table 4--is obtained by multiplying each cohort's net worth-income ratio or saving rate (as reported for 1992 and 2000 in tables 1 and 2) by its share of aggregate disposable income (as reported in appendix A). 
worth-income ratio climbed about 98 percentage points, while the aggregate saving rate fell 4.1 percentage points. ${ }^{22}$ The experiences of households in the uppermost 20 percent of the income distribution accounted for 79 and 4.0 percentage points of the aggregate changes in the net worth-income ratio and saving rate, respectively. According to the lower panel in table 5, together, households headed by persons with some college experience accounted for all of the aggregate increase in the net worth-income ratio between 1992 and 2000, and accounted for 3.6 percentage points of the 4-percentage point decrease in the aggregate saving rate.

We interpret these cohort-level data as providing compelling evidence of a direct link between the runup in aggregate household net worth caused by the U.S. stock market boom since the mid-1990s and the subsequent stepdown in the economy-wide rate of saving, as the same groups of households who benefited the most from gains in the stock market lowered their saving rates the most. If this conclusion is accurate, then an econometric analysis of our cohortlevel data might be expected to produce estimates of the marginal propensity to consume out of wealth in the neighborhood of typical econometric studies that use aggregate data. ${ }^{23}$ Thus, we next present new estimates of the marginal propensity to consume out of wealth.

\section{ECONOMETRIC EVIDENCE}

\section{Baseline estimates}

To quantify the effects of changes in wealth on saving behavior using our cohort data, we estimate the following regression equation using ordinary least squares:

\footnotetext{
22 These specific numbers refer to data that excludes the net worth and saving of DBs and nonprofit organizations.

${ }^{23}$ To be more precise, our descriptive analysis in this section suggests that a direct wealth effect can account for the decline in the aggregate saving rate between 1992 and 2000, even if only the wealthiest American families--those in the uppermost income quintile and the upper two education categories--actively responded to their exceptional capital gains from the stock market. Alternatively, the econometric analysis we describe in the next section is based on a framework that assumes that all households follow the same saving behavior (as approximated by the simple equation (1) below). Under this assumption, the estimated marginal propensity to consume out of wealth obtained from our income- and education-cohort data ought to lie in the range produced by econometric studies based on aggregate time-series data.
} 


$$
\frac{S_{j t}}{Y_{j t}}=\beta_{0}+\beta_{1} \frac{N W_{j t}}{Y_{j t}}+\gamma_{j}+\delta_{t}+\varepsilon_{j t},
$$

where the subscript $j$ indexes cohorts of households $(j=1,2, \ldots, \mathrm{J})$ and the subscript $t$ indexes periods of time $(t=1,2, \ldots, \mathrm{T})$. The dependent variable in this regression is the saving rate, and the explanatory variable of interest is the net worth-income ratio: The coefficient on the net worth-income ratio, $\beta_{1}$, approximately equals the negative of the marginal propensity to consume out of a dollar change in wealth. ${ }^{24}$ The parameters denoted $\gamma_{j}$ allow different cohorts to have different average saving rates independent of their net worth-income ratios, and are estimated as coefficients on dummy variables identifying the different household groups. The parameters denoted $\delta_{t}$ capture time-trends in the saving rate that are common to all cohorts of households, independent of trends in their net worth-income ratios; these are estimated as coefficients on dummy variables indicating different periods of time. Our baseline specification includes a full set of dummy variables for each time-series observation to allow for quarterly movements in saving rates that are common across the cohorts and unrelated to changes in net worth. We estimate separate regressions for the cohort data in which households are grouped by income quintile and by education category. Also, we separately estimate regressions for the definition of the household sector used by the Flow of Funds and for our alternative definition that excludes the activities of DB pensions and nonprofits.

Table 6 reports our baseline estimates of the marginal propensity to consume out of wealth $\left(m p c ;-\beta_{1}\right)$. The estimates range from about 3-1/4 to 5 cents-to-the-dollar, depending on whether households are grouped by income or education category and whether the activities of DB pensions and nonprofits are included in the net worth and saving series. These propensities to consume are statistically significant at conventional levels, and lie well within the range reported from more typical time-series econometric studies based exclusively on aggregate data. ${ }^{25}$

${ }^{24}$ This can be seen by multiplying both sides of the regression equation by $Y_{j t}$, and assuming that $S_{j t}=Y_{j t}-C_{j t}$. Then, $\partial C_{j t} / \partial N W_{j t}=-\beta_{l}$.

${ }^{25}$ For example, Davis and Palumbo (2001) report estimates for the marginal propensity to consume out of (total) household wealth that range from 3 to 6 cents-to-the-dollar using several alternative specifications of 
The remaining rows of the table speak to the economic significance of these parameter estimates--that is, how much of the observed changes in saving rates can be accounted for by the estimated marginal propensities to consume given the paths observed for household wealth in the context of equation (1). Row 3 reports the estimated contribution of the uppermost income and education groups to the aggregate saving rate. ${ }^{26}$ As shown in the left-hand columns of table 6 , the regression-based estimate of the size of the wealth effect for just the households in the uppermost 20 percent of the income distribution is large enough to explain all of the observed decline in the aggregate saving rate over the past decade (compare rows 3 and 5 in the left-hand column).

Meanwhile, according to the regressions estimated using the education-cohort data, the estimated wealth effect for families in the upper two education groups are large enough to account for about 70 percent of the decline in the aggregate saving rate between 1992 and 2000 (rows 3 and 5 in the right-hand column).

Row 4 of the table reports the contribution of wealth effects to the change in the aggregate saving rate for all five income quintiles and all four education cohorts, based on the estimated regression and the observed changes in net worth for the respective groups. According to the regressions estimated using the income-quintile data, the aggregate wealth effect more than explains the overall decline in the saving rate between 1992 and 2000 (compare rows 4 and 5 in the left-hand column). That is, according to the estimated equations, the aggregate saving rate would have risen last decade in the absence of the extraordinary runup in household wealth owing to the exceptional stock market gains. A slightly different picture for the path of saving over the 1990s comes from the regressions based on the education-cohort data. Comparing rows 4 and 5 in the right-hand column of table 6 , we see that in this case the observed decline in the aggregate

simple, long-run consumption functions. Poterba's (2000) survey of other estimates from the research literature also lie in this range.

${ }^{26}$ The value in row 3 is the product of three terms: 1 ) the estimated marginal propensity to consume out of wealth (reported in row 1 of table 6); 2) the change in net worth for the uppermost income quintile and the upper two education categories between 1992 and 2000 (reported in tables 2 and 3, respectively); and, 3) the share of aggregate disposable income accounted for by the respective groups (reported in appendix A). 
saving rate is just about what the equation would have expected given the observed change in household net worth and the estimated propensity to consume out of wealth of 3-1/2 (upper panel) and 4-1/4 (lower panel) cents-to-the-dollar. By implication, the education-cohort data suggest that in the absence of the runup in household wealth that occurred in the latter half of the last decade, the personal saving rate would have held steady near its level in the early 1990s.

The bottom line from this econometric analysis of the cohort-level data is that the observed decline in the rate of personal saving in the U.S. in the latter half of 1990s can be fully accounted for using a simple equation to approximate household saving behavior in the face of terrific capital gains from the stock market. The movements in net worth and saving are consistent with a wealth effect in the range of 3-1/2 to 5 cents on the dollar that applies to all families in the economy.

\section{Sensitivity analysis}

In addition to the results shown in table 6 , we considered a number of alternative specifications. In particular, we replaced the "real time" net worth-income ratio for each cohort with a (backward) moving average. This alternative mimics the possibility that households adjust their spending behavior gradually in response to accrued capital gains. ${ }^{27}$ We also estimated the regression using instrumental variables, rather than ordinary least squares. In this case, we used cohort-specific time trends to instrument the actual net worth-income ratios as another way to gauge the sensitivity of our estimates to "smoothing" out the quarterly net worth data. We also experimented with alternative specifications for the time trend in saving rates, which was assumed to apply to all cohorts equally in the baseline regression (through $\delta_{t}$ ). Specifically, we considered an alternative specification in which the lowest two income quintiles and the lowest education cohort were allowed to have a different underlying time trend for saving rates over the 1990s than the other cohorts (this pattern is suggested by inspection of the raw data in tables 2 and 3). As a final robustness check, we estimated our baseline equations using only data for the upper three

\footnotetext{
${ }^{27}$ Gradual adjustment by households to recognized and sustained changes in net worth is consistent with typical time-series estimates of consumption functions (see Davis and Palumbo, 2001, for example). Dynan and Maki (2000) also conclude, from their microeconomic study, that direct wealth effects tend to boost
} 
quintiles in the income distribution and the upper three education categories. This would be appropriate if households in the bottom of the income and education distributions obeyed very different consumption functions than others, which would violate our maintained assumptions (in the baseline regression) that there exists a common marginal propensity to consume out of net worth and a common time trend for underlying saving rates independent of net worth.

Overall, the various alternative specifications that we examined produced estimated propensities to consume out of wealth near the range shown in table 6. Estimates from the alternative specifications were bunched in the range of 3-1/2 to 4-1/2 cents to the dollar (slightly below the central tendency of estimates in table 6), and almost always indicated statistical significance at conventional levels. We conclude that our cohort-data on saving and net worth produce robust estimates for the marginal propensity to consume out of wealth in the range suggested by more typical, pure time-series econometric analysis.

Thus, our results provide strong evidence to support a direct view of the wealth effect on household consumption. This conclusion accords well with recent results of Dynan and Maki (2000), who have studied purely micro-level data from a series of Consumer Expenditure Surveys (taken from 1983 through 1999). Dynan and Maki estimate a significant positive correlation between changes in household expenditures over the four quarters in which they were in the survey and a household-specific estimate of capital gains. They also find no evidence that the spending of households who did not own corporate equities is related to movements in the stock market.

consumption over a period of many quarters. 


\section{Conclusions}

In this paper, we report on a newly constructed source of data that combines information about household balance sheets from the triennial Survey of Consumer Finances with quarterly data on aggregate balance sheets and saving flows published in the Flow of Funds accounts. Our reliance on the micro-data in the Survey of Consumer Finances to allocate the aggregate FFA net worth and saving data among cohorts ensures that the behavior of the wealthiest American families is accurately represented in our database. Given our findings that most of the aggregate trends in net worth and saving over the 1990s can be attributed to the experiences of households near the top of the income and education distributions, under-representation of these families in other commonly used microeconomic surveys (such as the PSID or CEX) implies that they may not be capable of reproducing trends in the aggregate economic series.

Furthermore, by allocating the aggregate levels of net worth and saving among cohorts-defined by income quintiles and education categories--our study provides a test of direct versus indirect wealth effects that cannot be addressed with aggregate data alone. According to the direct view, saving should have fallen among the same groups of households whose portfolios benefited disproportionately from the stock-market gains. In contrast, according to the indirect view, all households might have saved less of their incomes in response to the good macroeconomic news that drove up the stock market.

We first present descriptive evidence that is clearly consistent with a direct view of the wealth effect, whereby the acceleration in the rate of decline in the personal saving rate in the U.S. recorded since 1994 was shown to be generated by a pickup in the propensity to consume out of current income among families whose portfolios benefited from exceptional capital gains. Not surprisingly, the data confirm that, because they disproportionately held corporate equities in their portfolios, households at the top of the income and education distributions benefited disproportionately from the stock market boom in the second half of the 1990s. What is novel about our study is that it reveals, essentially for the first time, that these same cohorts of households whose portfolios surged in value decreased their saving rates sharply over this period. In fact, we show that the well-documented decline in the economy-wide rate of personal saving over the 1990 s can be attributed almost entirely to a sharp reduction in the saving rate of cohorts 
of families who experienced the largest capital gains.

In addition to our descriptive evidence, we present new estimates for the marginal propensity to consume out of wealth based on a regression analysis of our cohort-level, timeseries data. Across a wide range of alternative specifications, our parameter estimates usually lie between 3 and 5 cents-to-the-dollar. This range is well-aligned with typical estimates from timeseries econometric models based exclusively on aggregate data, and this econometric finding also supports our conclusion that the aggregate trends in household consumption and saving over the 1990s can be reasonably attributed to a direct view of the wealth effect.

Finally, note that some commentators have speculated that the degree of concentration in the U.S. wealth distribution militates against a direct view of wealth effects as explaining the latter-1990s consumption boom. Their reasoning seems to be that it would take implausibly large increases in spending by the richest Americans to generate the rapid growth rates observed in the aggregate expenditure data from 1994 to 2000. To the contrary, our direct investigation of saving rates across the income and education distributions, which properly accounts for the concentration of wealth, demonstrates that all of the consumption boom really can be attributed to the richest groups of households. Between 1992 and 2000, the level of aggregate saving, as measured in our data, fell about $\$ 200$ billion, reflecting a $\$ 240$ billion drop in the level of saving by households in the uppermost 20 percent of the income distribution that was only partially offset by a $\$ 40$ billion increase in saving among those in the lower 80 percent. This figure of $\$ 240$ billion represents 7-1/2 percent of the level of spending in 2000 for households in the uppermost 20 percent of the U.S. income distribution, which implies about a 1 percentage point increase in their average annual growth rate of spending over this period.

Thus, our paper is the first to both document a dramatic behavioral response of wealthy Americans to the stock-market boom that prevailed from 1994 through 1999, and demonstrate that the magnitude of this response is capable of accounting for virtually all of the decline in the aggregate personal saving rate last decade. 


\section{REFERENCES}

Antoniewicz, Rochelle L. 1996. "A Comparison of the Household Sector from the Flow of Funds Accounts and the Survey of Consumer Finances," Finance and Economics Discussion Series no. 1996-26 (July), Federal Reserve Board.

Davis, Morris A., and Michael G. Palumbo. 2001. "A Primer on the Economics and Time Series Econometrics of Wealth Effects," Finance and Economics Discussion Series no. 2001-09 (February), Federal Reserve Board.

Dynan, Karen E., and Dean M. Maki. 2000. “Does Stock Market Wealth Matter for Consumption?," mimeo, Board of Governors of the Federal Reserve System.

Kiley, Michael T. 2000. "Identifying the Effect of Stock Market Wealth on Consumption: Pitfalls and New Evidence," mimeo, Board of Governors of the Federal Reserve System.

Ludvigson, Sydney, and Charles Steindel. 1999. "How Important is the Stock Market Effect on Consumption?," Federal Reserve Bank of New York Economic Policy Review 5, no. 2 (July), pp. 29-52.

Muellbauer, John. 1994. "The Assessment: Consumer Expenditure," Oxford Review of Economic Policy 10, no. 2 (Summer), pp. 1-41.

Muellbauer, John, and Ralph Lattimore. 1995. "The Consumption Function: A Theoretical and Empirical Overview," in H. Pesaran and M. Wickens (eds.), Handbook of Applied Econometrics, Oxford, U.K.: Blackwell, pp. 221-311.

Poterba, James M. 2000. "Stock Market Wealth and Consumption," Journal of Economic Perspectives 14, no. 2 (Spring), pp. 99-118.

Poterba, James M., and Andrew A. Samwick. 1995. "Stock Ownership Patterns, Stock Market Fluctuations, and Consumption," Brookings Papers on Economic Activity, no. 2, pp. 295357.

Sabelhaus, John. 1998. "Using the Consumer Expenditure Survey for Research on Saving and Consumption," mimeo, Congressional Budget Office (May). 


\section{TABLE 1}

Shares of Detailed Asset and Liability Categories Held by Households in the Uppermost Quintile of the Income Distribution, by SCF Wave

\begin{tabular}{|c|c|c|c|c|c|}
\hline \multirow[b]{2}{*}{$\underline{\text { Item }}$} & \multirow[b]{2}{*}{ Description } & \multicolumn{4}{|c|}{ SCF Wave } \\
\hline & & $\underline{1989}$ & $\underline{1992}$ & 1995 & $\underline{1998}$ \\
\hline & Total Assets & .615 & .603 & .601 & .626 \\
\hline 1 & Owner-occupied real estate & .510 & .482 & .456 & .470 \\
\hline 2 & Consumer durable goods & .404 & .383 & .362 & .369 \\
\hline 3 & Checkable deposits & .484 & .477 & .492 & .513 \\
\hline 4 & Time and savings deposits & .525 & .478 & .502 & .471 \\
\hline 5 & Money market mutual funds & .810 & .792 & .772 & .756 \\
\hline 6 & U.S. Treasury and agency securities & .842 & .811 & .801 & .756 \\
\hline 7 & Savings bonds & .399 & .516 & .480 & .482 \\
\hline 8 & Municipal securities & .894 & .843 & .933 & .838 \\
\hline 9 & Corporate bonds & 691 & .810 & .798 & .714 \\
\hline 10 & Mortgage assets & .731 & .646 & .597 & .445 \\
\hline 11 & Publicly traded corporate equity & .811 & .810 & .831 & .831 \\
\hline 12 & Closely held corporate equity & .890 & .873 & .901 & .885 \\
\hline 13 & Mutual fund shares & .823 & .744 & .721 & .744 \\
\hline 14 & Life insurance reserves & .550 & .573 & .546 & .569 \\
\hline 15 & Defined contribution pension reserves & .743 & .732 & .694 & 678 \\
\hline 16 & Investment in bank personal trusts & .923 & .851 & .803 & .858 \\
\hline 17 & Equity in noncorporate business & .723 & .715 & .702 & .744 \\
\hline 18 & Other insurance policy payables & .404 & .383 & .362 & .369 \\
\hline & Total Liabilities & .594 & .560 & .529 & .532 \\
\hline 19 & Home mortgage debt & .605 & .588 & .546 & .547 \\
\hline 20 & Consumer credit & .555 & .471 & .489 & .481 \\
\hline 21 & Security credit & .995 & .946 & .984 & .836 \\
\hline 22 & Other liabilities & .592 & .578 & .537 & .544 \\
\hline
\end{tabular}

Note: This table reports the share of each detailed asset and liability category held by the twenty percent of households in the uppermost quintile of the (disposable) income distribution, as measured by the triennial SCFs from 1989 through 1992. 
TABLE 2

Net Worth-Income Ratios and Saving Rates by Income Quintile

A. Including defined benefit pension plans and nonprofit organizations in the measures of saving and net worth.

\begin{tabular}{|c|c|c|c||c|c|c|}
\hline & \multicolumn{3}{|c||}{ Net worth-income ratio } & \multicolumn{3}{c|}{ Saving rate } \\
Income Category & $\begin{array}{c}1992 \\
(\mathrm{~A})\end{array}$ & $\begin{array}{c}2000 \\
(\mathrm{~B})\end{array}$ & $\begin{array}{c}\text { Difference } \\
(\mathrm{B})-(\mathrm{A})\end{array}$ & $\begin{array}{c}1992 \\
(\mathrm{C})\end{array}$ & $\begin{array}{c}2000 \\
(\mathrm{D})\end{array}$ & $\begin{array}{c}\text { Difference } \\
(\mathrm{D})-(\mathrm{C})\end{array}$ \\
\hline Total & 468.6 & 612.7 & 144.1 & 5.9 & 1.3 & -4.6 \\
\hline $81 \%-100 \%$ & 639.5 & 869.2 & 229.7 & 8.5 & -2.1 & -10.6 \\
\hline $61 \%-80 \%$ & 332.2 & 417.1 & 84.9 & 4.7 & 2.6 & -2.1 \\
\hline $41 \%-60 \%$ & 326.7 & 364.9 & 38.2 & 2.7 & 2.9 & .2 \\
\hline $21 \%-40 \%$ & 328.2 & 414.5 & 86.3 & 4.2 & 7.4 & 3.2 \\
\hline $0 \%-20 \%$ & 411.3 & 512.3 & 101.0 & 3.8 & 7.1 & 3.3 \\
\hline
\end{tabular}

B. Excluding defined benefit pension plans and nonprofit organizations in the measures of saving and net worth.

\begin{tabular}{|c|c|c|c||c|c|c|}
\hline & \multicolumn{3}{|c||}{ Net worth-income ratio } & \multicolumn{3}{c|}{ Saving rate } \\
Income Category & $\begin{array}{c}1992 \\
(\mathrm{~A})\end{array}$ & $\begin{array}{c}2000 \\
(\mathrm{~B})\end{array}$ & $\begin{array}{c}\text { Difference } \\
(\mathrm{B})-(\mathrm{A})\end{array}$ & $\begin{array}{c}1992 \\
(\mathrm{C})\end{array}$ & $\begin{array}{c}2000 \\
(\mathrm{D})\end{array}$ & $\begin{array}{c}\text { Difference } \\
(\mathrm{D})-(\mathrm{C})\end{array}$ \\
\hline Total & 389.4 & 487.1 & 97.7 & 3.4 & -.7 & -4.1 \\
\hline $81 \%-100 \%$ & 536.2 & 706.9 & 170.7 & 4.9 & -4.4 & -9.3 \\
\hline $61 \%-80 \%$ & 270.7 & 318.5 & 47.8 & 2.7 & 1.1 & -1.6 \\
\hline $41 \%-60 \%$ & 276.3 & 284.4 & 8.1 & 1.3 & 1.4 & .1 \\
\hline $21 \%-40 \%$ & 262.3 & 311.7 & 49.4 & 2.6 & 5.5 & 2.9 \\
\hline $0 \%-20 \%$ & 329.3 & 385.4 & 56.1 & 2.1 & 4.4 & 2.2 \\
\hline
\end{tabular}

Note: Ratios have been multiplied by 100. Components may not sum to totals due to rounding. Data shown are annual averages of underlying quarterly series; data for 2000 are based on observations from Q1 through Q3. 
TABLE 3

Net Worth-Income Ratios and Saving Rates by Education Category

A. Including defined benefit pension plans and nonprofit organizations in the measures of saving and net worth.

\begin{tabular}{|c|c|c|c||c|c|c|}
\hline \multirow{2}{*}{} & \multicolumn{3}{|c||}{ Net worth-income ratio } & \multicolumn{3}{c|}{ Saving rate } \\
$\begin{array}{c}\text { Education } \\
\text { Category }\end{array}$ & $\begin{array}{c}1992 \\
\text { (A) }\end{array}$ & $\begin{array}{c}2000 \\
(\mathrm{~B})\end{array}$ & $\begin{array}{c}\text { Difference } \\
(\mathrm{B})-(\mathrm{A})\end{array}$ & $\begin{array}{c}1992 \\
(\mathrm{C})\end{array}$ & $\begin{array}{c}2000 \\
(\mathrm{D})\end{array}$ & $\begin{array}{c}\text { Difference } \\
(\mathrm{D})-(\mathrm{C})\end{array}$ \\
\hline Total & 472.2 & 612.7 & 140.5 & 5.9 & 1.3 & -4.6 \\
\hline College degree & 580.4 & 721.8 & 141.4 & 7.2 & .7 & -6.5 \\
\hline Some college & 584.1 & 744.7 & 160.6 & 6.1 & .7 & -6.8 \\
\hline $\begin{array}{c}\text { High school } \\
\text { degree }\end{array}$ & 323.5 & 401.0 & 77.5 & 4.5 & 1.9 & -2.6 \\
\hline $\begin{array}{c}\text { No high school } \\
\text { degree }\end{array}$ & 234.1 & 321.4 & 87.3 & 3.4 & 4.2 & .8 \\
\hline
\end{tabular}

B. Excluding defined benefit pension plans and nonprofit organizations in the measures of saving and net worth.

\begin{tabular}{|c|c|c|c|c|c|c|}
\hline \multirow[b]{2}{*}{$\begin{array}{c}\text { Education } \\
\text { Category }\end{array}$} & \multicolumn{3}{|c|}{ Net worth-income ratio } & \multicolumn{3}{|c|}{ Saving rate } \\
\hline & $\begin{array}{l}1992 \\
(\mathrm{~A})\end{array}$ & $\begin{array}{c}2000 \\
(\mathrm{~B})\end{array}$ & $\begin{array}{l}\text { Difference } \\
(\mathrm{B})-(\mathrm{A})\end{array}$ & $\begin{array}{l}1992 \\
(\mathrm{C})\end{array}$ & $\begin{array}{l}2000 \\
\text { (D) }\end{array}$ & $\begin{array}{l}\text { Difference } \\
\text { (D) - (C) }\end{array}$ \\
\hline Total & 393.2 & 487.1 & 93.9 & 3.3 & -.7 & -4.0 \\
\hline College degree & 490.8 & 593.6 & 102.8 & 4.6 & -1.5 & -6.1 \\
\hline Some college & 503.5 & 619.8 & 116.3 & 3.7 & -1.4 & -5.1 \\
\hline High school degree & 254.9 & 279.8 & 24.9 & 1.9 & .4 & -1.5 \\
\hline $\begin{array}{l}\text { No high school } \\
\text { degree }\end{array}$ & 173.7 & 197.3 & 23.6 & 1.1 & 2.8 & 1.7 \\
\hline
\end{tabular}

Note: Ratios have been multiplied by 100. Components may not sum to totals due to rounding. Data shown are annual averages of underlying quarterly series; data for 2000 are based on observations from Q1 through Q3. 


\section{TABLE 4}

Contributions to the Aggregate Net Worth-Income Ratio and Saving Rate, by Income Quintile

A. Including defined benefit pension plans and nonprofit organizations in the measures of saving and net worth.

\begin{tabular}{|c|c|c|c||c|c|c|}
\hline & \multicolumn{3}{|c||}{ Net worth-income ratio } & \multicolumn{3}{c|}{ Saving rate } \\
Income Category & $\begin{array}{c}1992 \\
(\mathrm{~A})\end{array}$ & $\begin{array}{c}2000 \\
(\mathrm{~B})\end{array}$ & $\begin{array}{c}\text { Difference } \\
(\mathrm{B})-(\mathrm{A})\end{array}$ & $\begin{array}{c}1992 \\
(\mathrm{C})\end{array}$ & $\begin{array}{c}2000 \\
(\mathrm{D})\end{array}$ & $\begin{array}{c}\text { Difference } \\
(\mathrm{D})-(\mathrm{C})\end{array}$ \\
\hline Total & 468.6 & 612.7 & 144.1 & 5.9 & 1.3 & -4.6 \\
\hline $81 \%-100 \%$ & 279.4 & 385.1 & 105.7 & 3.7 & -.9 & -4.6 \\
\hline $61 \%-80 \%$ & 81.4 & 100.9 & 19.5 & 1.2 & .6 & -.6 \\
\hline $41 \%-60 \%$ & 54.9 & 60.2 & 5.3 & .5 & .5 & .0 \\
\hline $21 \%-40 \%$ & 34.8 & 43.9 & 9.1 & .5 & .8 & .3 \\
\hline $0 \%-20 \%$ & 18.1 & 22.5 & 4.4 & .2 & .3 & .1 \\
\hline
\end{tabular}

B. Excluding defined benefit pension plans and nonprofit organizations in the measures of saving and net worth.

\begin{tabular}{|c|c|c|c||c|c|c|}
\hline & \multicolumn{3}{|c||}{ Net worth-income ratio } & \multicolumn{3}{c|}{ Saving rate } \\
Income Category & $\begin{array}{c}1992 \\
(\mathrm{~A})\end{array}$ & $\begin{array}{c}2000 \\
(\mathrm{~B})\end{array}$ & $\begin{array}{c}\text { Difference } \\
(\mathrm{B})-(\mathrm{A})\end{array}$ & $\begin{array}{c}1992 \\
(\mathrm{C})\end{array}$ & $\begin{array}{c}2000 \\
(\mathrm{D})\end{array}$ & $\begin{array}{c}\text { Difference } \\
(\mathrm{D})-(\mathrm{C})\end{array}$ \\
\hline Total & 389.4 & 487.1 & 97.7 & 3.4 & -.7 & -4.1 \\
\hline $81 \%-100 \%$ & 234.3 & 313.2 & 78.9 & 2.1 & -1.9 & -4.0 \\
\hline $61 \%-80 \%$ & 66.3 & 77.1 & 10.8 & .7 & .3 & -.4 \\
\hline $41 \%-60 \%$ & 46.4 & 46.9 & .5 & .2 & .2 & .0 \\
\hline $21 \%-40 \%$ & 27.8 & 33.0 & 5.2 & .3 & .6 & .3 \\
\hline $0 \%-20 \%$ & 14.5 & 17.0 & 2.5 & .1 & .2 & .1 \\
\hline
\end{tabular}

Note: Ratios have been multiplied by 100. Components may not sum to totals due to rounding. Data shown are annual averages of underlying quarterly series; data for 2000 are based on observations from Q1 through Q3. 


\section{TABLE 5}

Contributions to the Aggregate Net Worth-Income Ratio and Saving Rate, by Education Category

A. Including defined benefit pension plans and nonprofit organizations in the measures of saving and net worth.

\begin{tabular}{|c|c|c|c||c|c|c|}
\hline \multirow{2}{*}{} & \multicolumn{3}{|c||}{ Net worth-income ratio } & \multicolumn{3}{c|}{ Saving rate } \\
$\begin{array}{c}\text { Education } \\
\text { Category }\end{array}$ & $\begin{array}{c}1992 \\
\text { (A) }\end{array}$ & $\begin{array}{c}2000 \\
(\mathrm{~B})\end{array}$ & $\begin{array}{c}\text { Difference } \\
(\mathrm{B})-(\mathrm{A})\end{array}$ & $\begin{array}{c}1992 \\
(\mathrm{C})\end{array}$ & $\begin{array}{c}2000 \\
(\mathrm{D})\end{array}$ & $\begin{array}{c}\text { Difference } \\
(\mathrm{D})-(\mathrm{C})\end{array}$ \\
\hline Total & 472.2 & 612.7 & 140.5 & 5.9 & 1.3 & -4.6 \\
\hline College degree & 256.6 & 355.8 & 99.2 & 3.2 & .3 & -2.9 \\
\hline Some college & 100.6 & 130.3 & 29.7 & 1.1 & .1 & -1.0 \\
\hline $\begin{array}{c}\text { High school } \\
\text { degree }\end{array}$ & 89.9 & 100.0 & 10.1 & 1.3 & .5 & -.8 \\
\hline $\begin{array}{c}\text { No high school } \\
\text { degree }\end{array}$ & 25.3 & 26.7 & 1.4 & .4 & .4 & .0 \\
\hline
\end{tabular}

B. Excluding defined benefit pension plans and nonprofit organizations in the measures of saving and net worth.

\begin{tabular}{|c|c|c|c||c|c|c|}
\hline \multirow{2}{*}{$\begin{array}{c}\text { Education } \\
\text { Category }\end{array}$} & \multicolumn{3}{|c||}{ Net worth-income ratio } & \multicolumn{3}{c|}{ Saving rate } \\
\hline Total & 3992 & $\begin{array}{c}2000 \\
(\mathrm{~B})\end{array}$ & $\begin{array}{c}\text { Difference } \\
(\mathrm{B})-(\mathrm{A})\end{array}$ & $\begin{array}{c}1992 \\
(\mathrm{C})\end{array}$ & $\begin{array}{c}2000 \\
\text { (D) }\end{array}$ & $\begin{array}{c}\text { Difference } \\
\text { (D) - (C) }\end{array}$ \\
\hline College degree & 216.9 & 292.6 & 75.7 & 2.0 & -.7 & -4.0 \\
\hline Some college & 86.6 & 108.5 & 21.9 & .6 & -.3 & -.9 \\
\hline High school degree & 70.9 & 69.7 & -1.2 & .5 & .1 & -.4 \\
\hline $\begin{array}{c}\text { No high school } \\
\text { degree }\end{array}$ & 18.8 & 16.4 & -2.4 & .1 & .2 & .1 \\
\hline
\end{tabular}

Note: Ratios have been multiplied by 100. Components may not sum to totals due to rounding. Data shown are annual averages of underlying quarterly series; data for 2000 are based on observations from Q1 through Q3. 
TABLE 6

Estimates of the Marginal Propensity to Consume Out of Wealth and Fitted Values for the Change in the Saving Rate from the Baseline Regression Equation

A. Including defined benefit pension plans and nonprofit organizations in the measures of saving and net worth.

\begin{tabular}{|c|c|c|c|}
\hline & \multirow[b]{2}{*}{ Model estimates: } & \multicolumn{2}{|c|}{ Households grouped by: } \\
\hline & & Income quintile & Education category \\
\hline 1 & Marginal propensity to consume out of wealth & .047 & .034 \\
\hline 2 & Standard error & .0063 & .0098 \\
\hline & \multicolumn{3}{|c|}{$\begin{array}{l}\text { Model predictions for the effects of changes in net worth on changes in } \\
\text { the aggregate saving rate, } 1992-2000 \text { : }\end{array}$} \\
\hline 3 & $\begin{array}{l}\text { Predicted contribution for just the uppermost income } \\
\text { and education groups }\end{array}$ & -4.8 & -3.2 \\
\hline 4 & $\begin{array}{l}\text { Predicted contribution for all income and education } \\
\text { Groups }\end{array}$ & -6.8 & -4.8 \\
\hline 5 & Actual change in the aggregate saving rate & -4.6 & -4.6 \\
\hline
\end{tabular}

B. Excluding defined benefit pension plans and nonprofit organizations in the measures of saving and net worth.

\begin{tabular}{|c|c|c|c|}
\hline & \multirow[b]{2}{*}{ Model estimates: } & \multicolumn{2}{|c|}{ Households grouped by: } \\
\hline & & Income quintile & Education category \\
\hline 1 & Marginal propensity to consume out of wealth & .050 & .043 \\
\hline 2 & Standard error & .0067 & .0085 \\
\hline & \multicolumn{3}{|c|}{$\begin{array}{l}\text { Model predictions for the effects of changes in net worth on changes in } \\
\text { the aggregate saving rate, } 1992-2000 \text { : }\end{array}$} \\
\hline 3 & $\begin{array}{l}\text { Predicted contribution for just the uppermost income } \\
\text { and education groups }\end{array}$ & -3.8 & -2.8 \\
\hline 4 & $\begin{array}{l}\text { Predicted contribution for all income and education } \\
\text { Groups }\end{array}$ & -4.9 & -4.0 \\
\hline 5 & Actual change in the aggregate saving rate & -4.1 & -4.1 \\
\hline
\end{tabular}


FIGURE 1

Personal Saving Rate and the Ratio of Net Worth to Disposable Income (1953:Q1 - 2000:Q3)

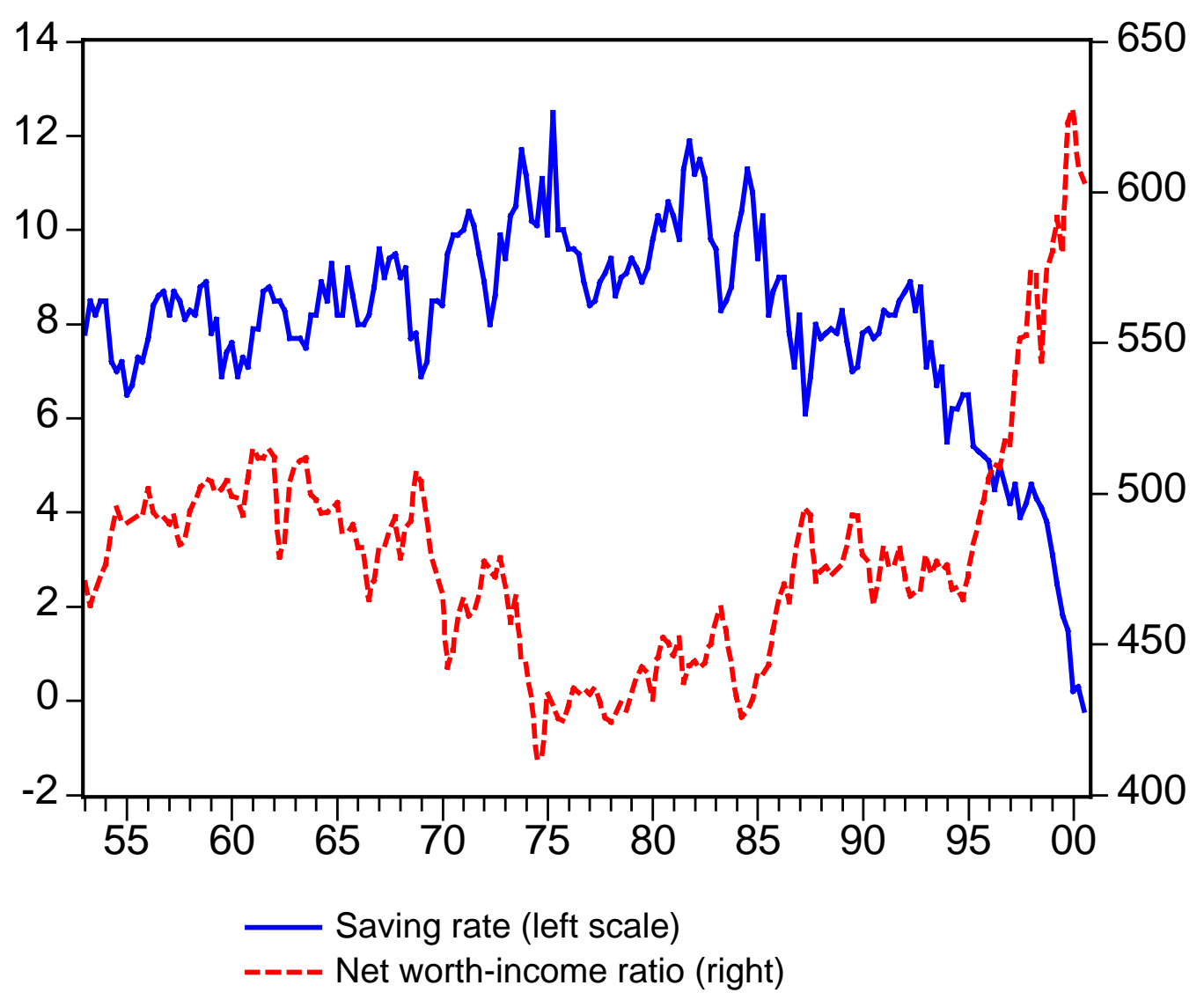

Note: Personal saving and disposable personal income are published by the Bureau of Economic Analysis (BEA); household net worth is published by the Federal Reserve Board. 


\section{FIGURE 2}

Measures of Personal Saving from the

National Income and Product Accounts and the Flow of Funds

(Four-quarter moving averages; 1970:Q1-2000:Q3)

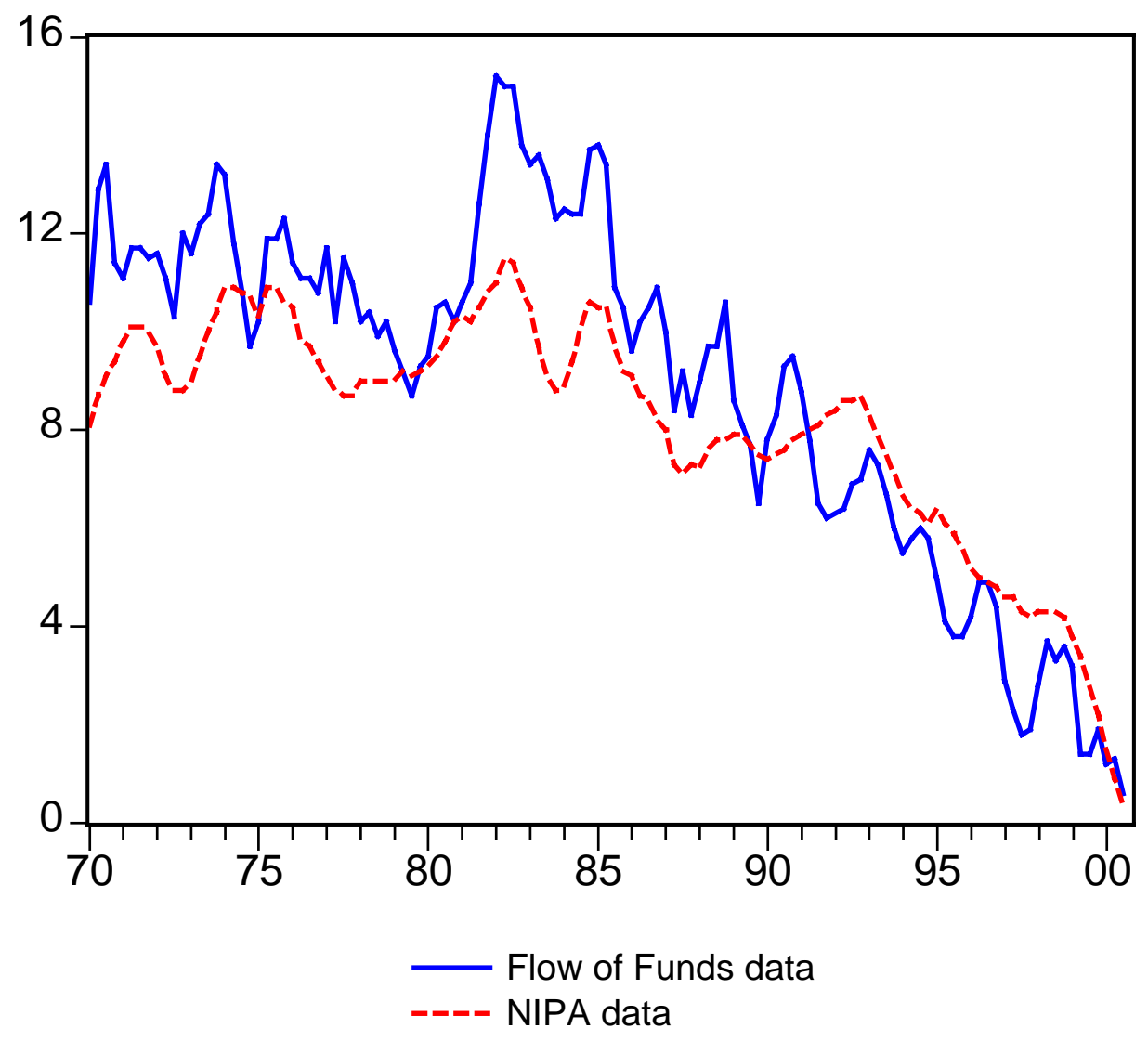

Note: Personal saving, as measured conceptually in the National Income and Product Accounts (NIPA) as a percentage of NIPA disposable income. 


\section{FIGURE 3}

Net Worth-Income Ratios by Income Quintile: Excluding Defined Benefit Pension Plans and Nonprofit Organizations (1992:Q1 - 2000:Q3)
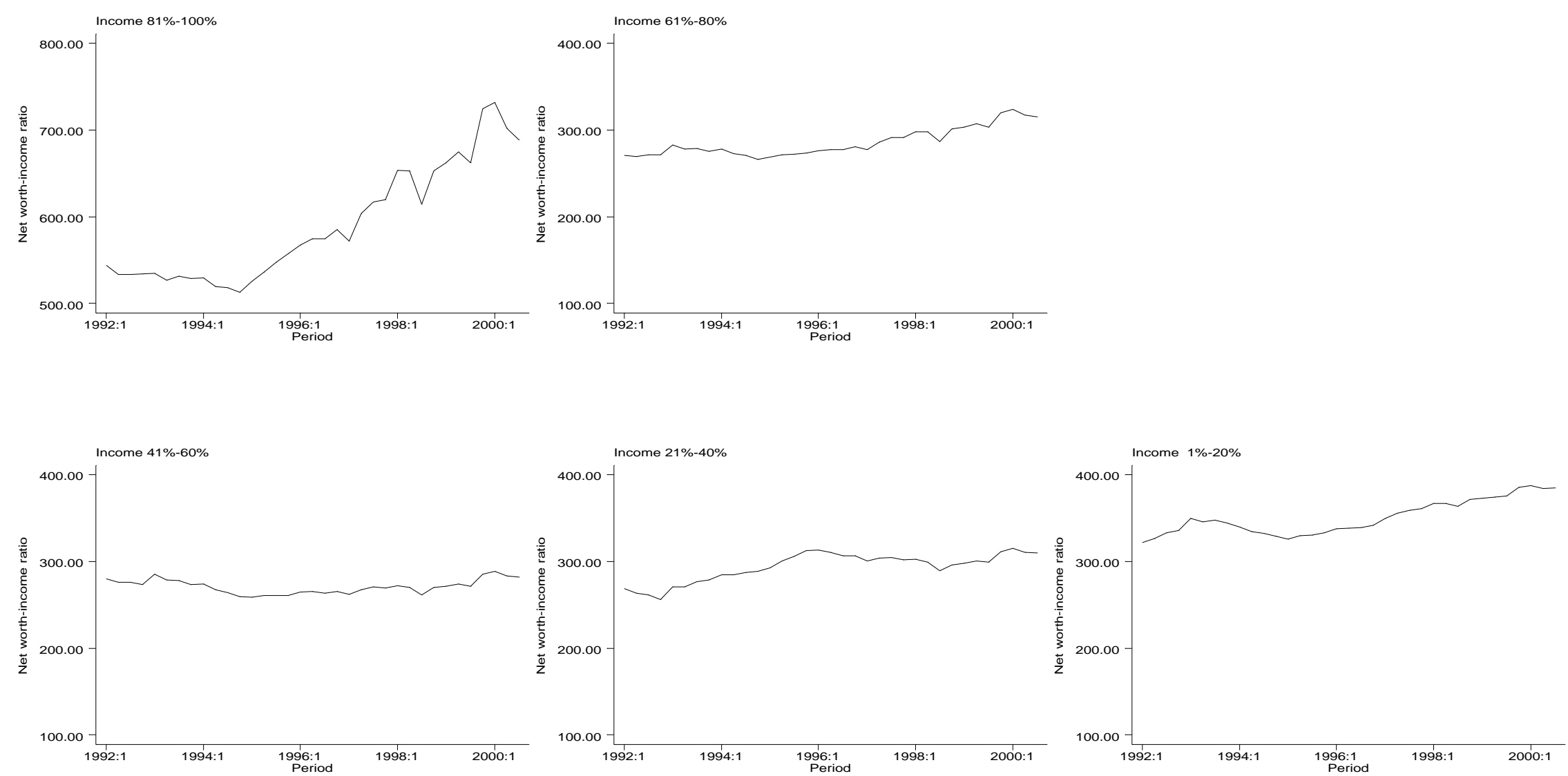


\section{FIGURE 4}

Saving Rates by Income Quintile: Excluding Defined Benefit Pension Plans and Nonprofit Organizations (1992:Q1 - 2000:Q3)
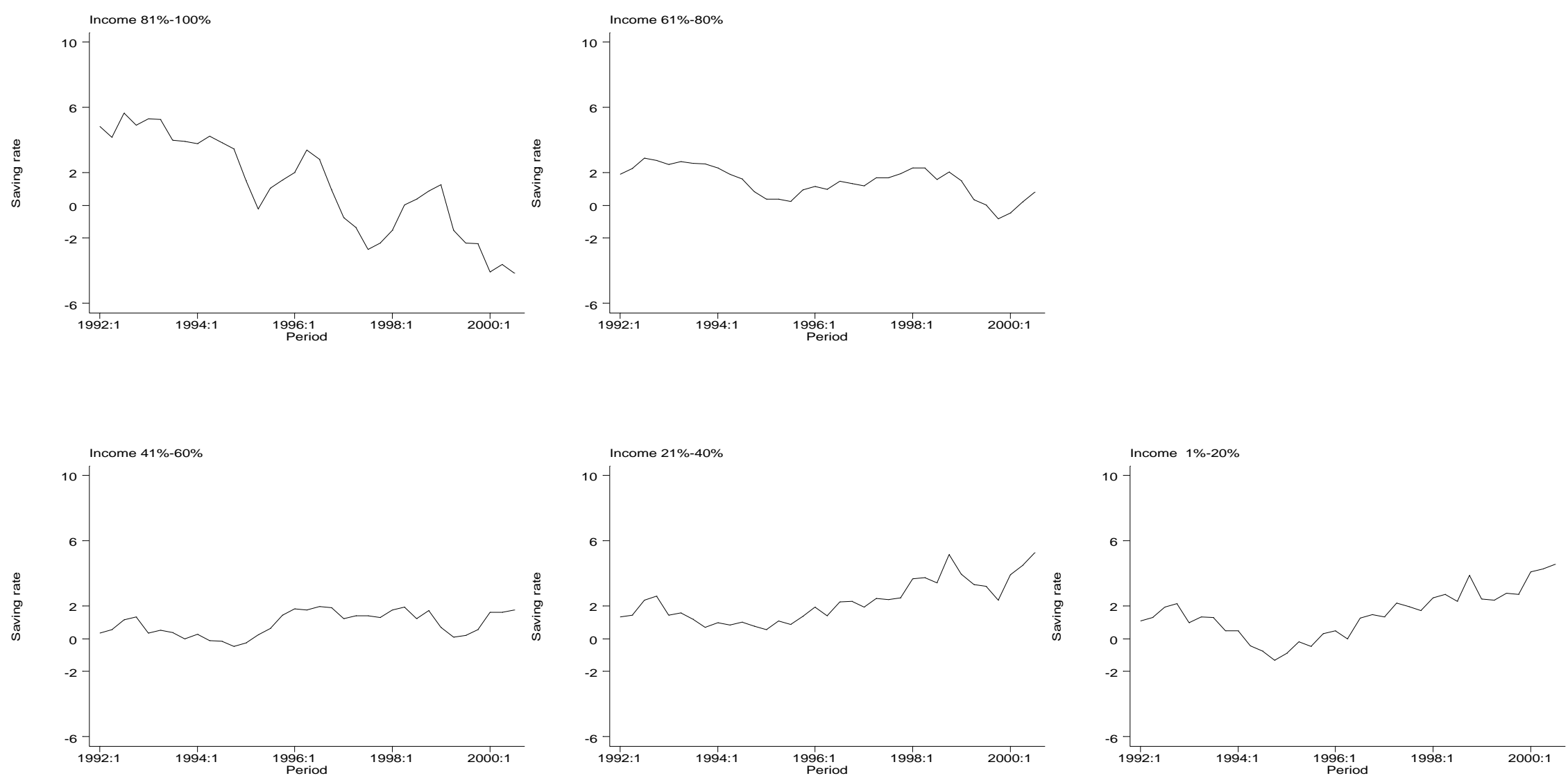


\section{FIGURE 5}

Net Worth-Income Ratios by Education Category: Excluding Defined Benefit Pension Plans and Nonprofit Organizations (1992:Q1 - 2000:Q3)
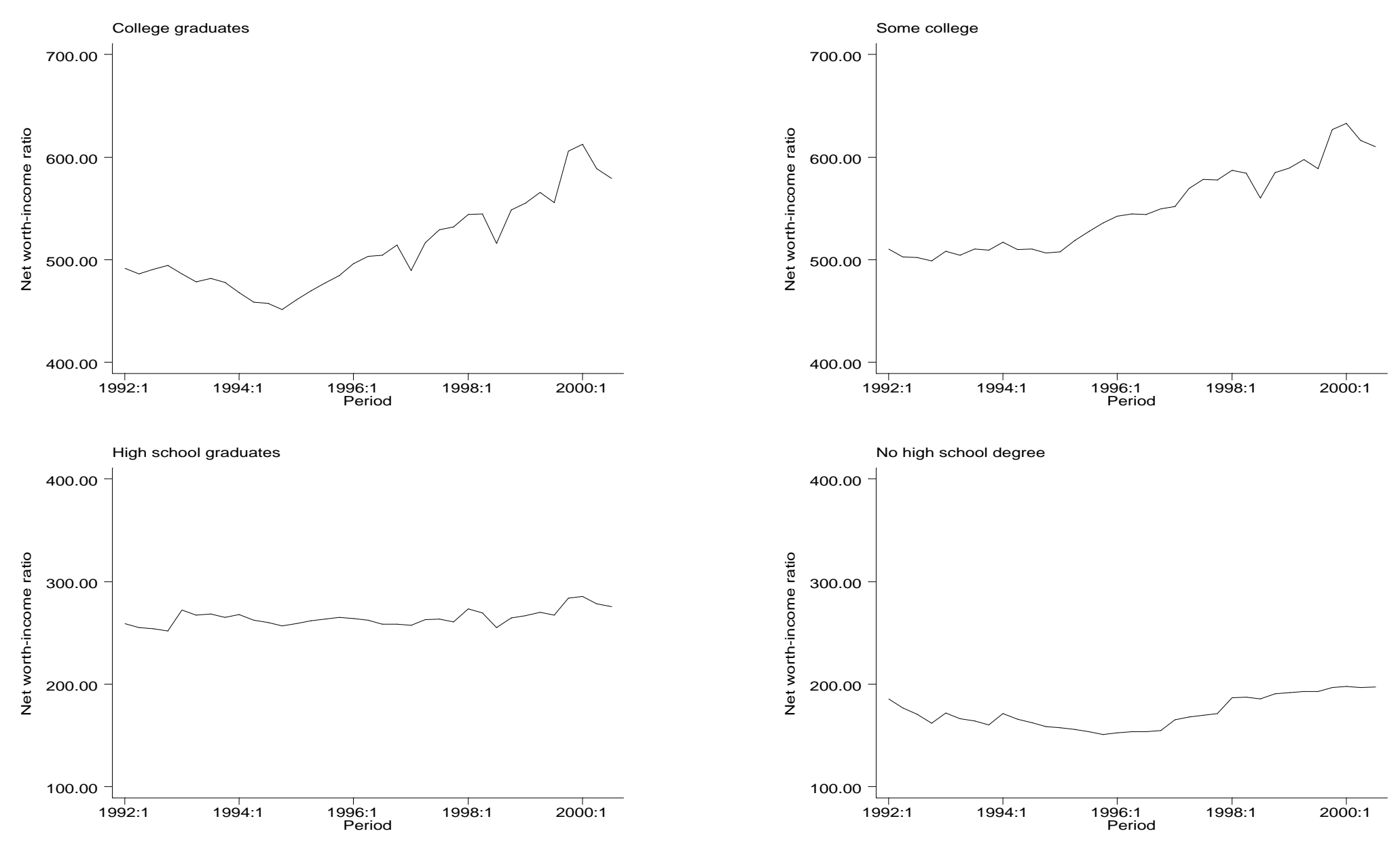


\section{FIGURE 6}

Saving Rates by Education Category: Excluding Defined Benefit Pension Plans and Nonprofit Organizations (1992:Q1 - 2000:Q3)
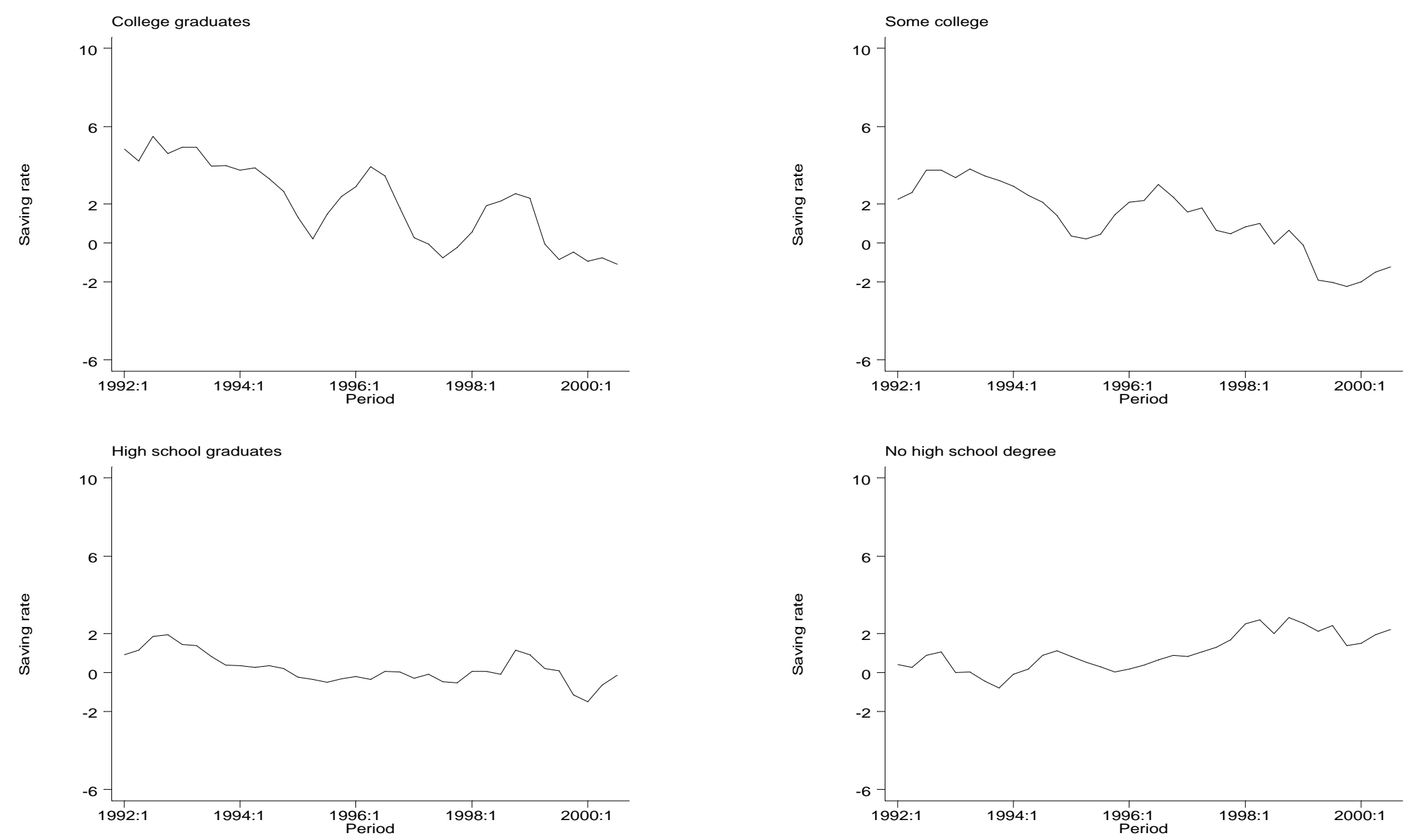


\section{APPENDIX A}

Shares of Aggregate Disposable Income by Income Quintile and Education Category

A. Income quintiles

\begin{tabular}{|c|c|c|c|}
\hline \multirow{2}{*}{ Income Category } & \multicolumn{3}{|c|}{ Share of Aggregate Disposable Income } \\
\hline Total & 1992 & 2000 & $\begin{array}{c}\text { Difference } \\
(\mathrm{A})\end{array}$ \\
\hline $81 \%-100 \%$ & 100.0 & 100.0 & -- \\
\hline $61 \%-80 \%$ & 43.7 & 44.3 & .7 \\
\hline $41 \%-60 \%$ & 24.5 & 24.2 & -.3 \\
\hline $21 \%-40 \%$ & 16.8 & 16.5 & -.3 \\
\hline $0 \%-20 \%$ & 10.6 & 10.6 & .0 \\
\hline
\end{tabular}

B. Education categories

\begin{tabular}{|c|c|c|c|}
\hline \multirow{2}{*}{ Education Category } & \multicolumn{3}{|c|}{ Share of Aggregate Disposable Income } \\
& 1992 & $\begin{array}{c}2000 \\
\text { (A) }\end{array}$ & $\begin{array}{c}\text { Difference } \\
\text { (B) }-(\mathrm{A})\end{array}$ \\
\hline Total & 100.0 & 100.0 & -- \\
\hline College degree & 44.2 & 49.3 & 5.1 \\
\hline Some college & 17.2 & 17.5 & .3 \\
\hline High school degree & 27.8 & 24.9 & -2.9 \\
\hline $\begin{array}{c}\text { No high school } \\
\text { degree }\end{array}$ & 10.8 & 8.3 & -2.5 \\
\hline
\end{tabular}

Note: Ratios have been multiplied by 100 . Components may not sum to totals due to rounding. Data shown are annual averages of underlying quarterly series; data for 2000 are based on observations from Q1 through Q3. 


\section{APPENDIX B}

Shares of Aggregate Net Worth by Income Quintile and Education Category

A. Income quintiles

\begin{tabular}{|c|c|c|c|}
\hline \multirow{2}{*}{ Income Category } & \multicolumn{3}{|c|}{ Share of Aggregate Net Worth } \\
\hline Total & 1992 & 2000 & $\begin{array}{c}\text { Difference } \\
(\mathrm{A})\end{array}$ \\
\hline $81 \%-100 \%$ & 100.0 & 100.0 & $-(\mathrm{B})$ \\
\hline $61 \%-80 \%$ & 59.6 & 62.9 & 3.3 \\
\hline $41 \%-60 \%$ & 17.4 & 16.5 & -.9 \\
\hline $21 \%-40 \%$ & 11.7 & 9.8 & -1.9 \\
\hline $0 \%-20 \%$ & 7.4 & 7.2 & -.2 \\
\hline
\end{tabular}

B. Education categories

\begin{tabular}{|c|c|c|c|}
\hline \multirow[b]{2}{*}{ Education Category } & \multicolumn{3}{|c|}{ Share of Aggregate Net Worth } \\
\hline & $\begin{array}{c}1992 \\
(\mathrm{~A})\end{array}$ & $\begin{array}{c}2000 \\
\text { (B) }\end{array}$ & $\begin{array}{c}\text { Difference } \\
(\mathrm{B})-(\mathrm{A})\end{array}$ \\
\hline Total & 100.0 & 100.0 & --- \\
\hline College degree & 55.2 & 60.1 & 4.9 \\
\hline Some college & 22.0 & 22.3 & .3 \\
\hline High school degree & 18.0 & 14.3 & -3.7 \\
\hline $\begin{array}{c}\text { No high school } \\
\text { degree }\end{array}$ & 4.8 & 3.4 & -1.4 \\
\hline
\end{tabular}

Note: Ratios have been multiplied by 100 . Components may not sum to totals due to rounding. Data shown are annual averages of underlying quarterly series; data for 2000 are based on observations from Q1 through Q3. The net worth series includes the activities of defined benefit pension plans and nonprofit organizations. 


\section{APPENDIX C}

Shares of Aggregate Consumer Expenditure by Income Quintile and Education Category

A. Income quintiles

\begin{tabular}{|c|c|c|c|}
\hline \multirow{2}{*}{ Income Category } & \multicolumn{3}{|c|}{ Share of Aggregate Consumer Expenditure } \\
& 1992 & 2000 & $\begin{array}{c}\text { Difference } \\
(\mathrm{A})\end{array}$ \\
\hline Total & 100.0 & 100.0 & - (A) \\
\hline $81 \%-100 \%$ & 42.5 & 45.8 & 3.3 \\
\hline $61 \%-80 \%$ & 24.8 & 23.9 & -.9 \\
\hline $41 \%-60 \%$ & 17.4 & 16.2 & -1.2 \\
\hline $21 \%-40 \%$ & 10.8 & 9.9 & -.9 \\
\hline $0 \%-20 \%$ & 4.5 & 4.1 & -.4 \\
\hline
\end{tabular}

B. Education categories

\begin{tabular}{|c|c|c|c|}
\hline \multirow{2}{*}{ Education Category } & \multicolumn{3}{|c|}{ Share of Aggregate Consumer Expenditure } \\
& $\begin{array}{c}1992 \\
\text { (A) }\end{array}$ & $\begin{array}{c}2000 \\
\text { (B) }\end{array}$ & $\begin{array}{c}\text { Difference } \\
\text { (B) }-(\mathrm{A})\end{array}$ \\
\hline Total & 100.0 & 100.0 & -- \\
\hline College degree & 43.6 & 49.6 & 6.0 \\
\hline Some college & 17.2 & 17.6 & .4 \\
\hline High school degree & 28.2 & 24.7 & -3.5 \\
\hline $\begin{array}{c}\text { No high school } \\
\text { degree }\end{array}$ & 11.1 & 8.0 & -3.1 \\
\hline
\end{tabular}

Note: Consumer expenditure is approximated by the difference between levels of disposable income and saving. Ratios have been multiplied by 100. Components may not sum to totals due to rounding. Data shown are annual averages of underlying quarterly series; data for 2000 are based on observations from Q1 through Q3. The saving series used to construct consumer expenditures includes the activities of defined benefit pension plans and nonprofit organizations. 